\title{
Teaching medical ethics to experienced staff: participants, teachers and method
}

Tore Nilstun, Marina Cuttini and Rodolfo Saracci Lund University, Sweden, Burlo Garofolo Children's Hospital, Trieste, Italy and National Research Council, Pisa, Italy respectively

\begin{abstract}
Almost all articles on education in medical ethics present proposals for or describe experiences of teaching students in different health professions. Since

experienced staff also need such education, the purpose of this paper is to exemplify and discuss educational approaches that may be used after graduation. As an example we describe the experiences with a five-day European residential course on ethics for neonatal intensive care personnel. In this multidisciplinary course, using a case-based approach, the aim was to enhance the participants' understanding of ethical principles and their relevance to clinical and research activities. Our conclusion is that working with realistic cases encourages practising nurses and physicians to apply their previous knowledge and new concepts learnt in the course, thus helping them to bridge the gap between theory and practice.

(Fournal of Medical Ethics 2001;27:409-412)
\end{abstract}

Keywords: Case method; medical ethics education; neonatal intensive care personnel

\section{Introduction}

There is growing interest in education in the field of medical ethics within the health care profession. A search on MEDLINE in July 2000, using “(teach * OR educat $\left.{ }^{\star}\right)$ AND ethic ${ }^{\star}$ ", resulted in 5672 hits. In the Fournal of Medical Ethics we found 149 contributions. Almost all these articles deal with proposals for or experience of teaching undergraduate students. Within medical faculties the establishment of ethics programmes is also becoming increasingly common, and medical ethics has been a highly successful addition to educational curricula worldwide. This is, for instance, indicated by a survey of 206 medical schools in Asia. ${ }^{1}$ Unlike undergraduate students, however, experienced staff have few opportunities for further education which addresses their special problems. In answering a self-administered questionnaire on ethical decision making in neonatal intensive care (EURONIC project), a number of nurses and physicians from eight European countries emphasised the need for more training in medical ethics related to their own field. ${ }^{2}$ Thus, it seems that many fully trained professionals could be better equipped when facing ethical problems in their everyday practice. Over the last ten years, the Fournal of Medical Ethics has only had three articles describing courses for experienced personnel: one in which senior doctors were introduced to narrative ethics, ${ }^{3}$ one for registered nurses using role-play, ${ }^{4}$ and one in which medical house officers were randomised and given different courses in medical ethics. ${ }^{5}$ More are needed. In our opinion, it is very important that we share our experiences with each other.

\section{Objectives}

The main purpose of this article is to describe and discuss educational approaches that may be used in teaching medical ethics after graduation: who should be taught, who should teach, and with what methods. As an example of one way to answer these questions, we describe our own experiences with a European residential course that took place in Florence, Italy during one week in the spring of 1998. The course was a cooperative project between an ethicist (TN) and a neonatologist (MC), in collaboration with an epidemiologist (RS).

\section{Who should be taught?}

All health care professionals have to face ethically problematic situations, and therefore may certainly benefit from education in the theory and practice of ethics. It is particularly important, however, that the specialists who face the most difficult decisions, such as those around the beginning and end of life, receive specific support and training. ${ }^{6}$ The Florence course was specifically targeted at experienced doctors and nurses from neonatal intensive care units in Europe. In all 20 males, and 22 females ( 15 nurses, 26 physicians, and one statistician) from 12 different countries participated. Five came from outside Europe (one from Canada and four from the USA). Funds to support attendance for both participant staff (16 junior fellowships) and faculty were made available by the programme for Training and Mobility of Researchers (TMR) of the European Union. We are aware that substantial funding for teaching of this kind may be the exception rather than the rule. We believe, however, that the main elements of our experience may be applied on 
410 Teaching and learning medical ethics: Teaching medical ethics to experienced staff: participants, teachers and method

Table 1 The structure and content of the Florence course

\begin{tabular}{|c|c|c|c|c|}
\hline Day & Foundations & Principles & Case-studies & Evening lecturers \\
\hline 1 & $\begin{array}{l}\text { Why care about } \\
\text { consequences? }\end{array}$ & $\begin{array}{l}\text { Beneficence and } \\
\text { non-maleficence }\end{array}$ & $\begin{array}{l}\text { Extreme prematurity from induced } \\
\text { abortion }\end{array}$ & Euthanasia and the newborn \\
\hline 2 & Free will and responsibility & $\begin{array}{l}\text { Autonomy and respect for } \\
\text { person }\end{array}$ & $\begin{array}{l}\text { Intensive care in a situation of fatal } \\
\text { disease }\end{array}$ & $\begin{array}{l}\text { Fetuses, newborn and } \\
\text { personhood }\end{array}$ \\
\hline 3 & Can justice be justified? & $\begin{array}{l}\text { Non-discrimination and } \\
\text { solidarity }\end{array}$ & The Arthur case & Priorities in health care \\
\hline 4 & $\begin{array}{l}\text { To generalise or not to } \\
\text { generalise? }\end{array}$ & Free time & $\begin{array}{l}\text { Fetus/infant in research. Vaccination } \\
\text { trial }\end{array}$ & $\begin{array}{l}\text { The role of prognostic } \\
\text { uncertainty }\end{array}$ \\
\hline 5 & $\begin{array}{l}\text { The relevance of ethical } \\
\text { theories }\end{array}$ & Free time & Free time & $\begin{array}{l}\text { The EURONIC-project: } \\
\text { end-of-life decisions in } \\
\text { neonatal medicine }\end{array}$ \\
\hline
\end{tabular}

a national or local basis. One of the aspects which is certainly worth emphasising is the combination of professions sharing the same field and the same day-to-day activities. The different members of a team, in this case doctors and nurses, were given the opportunity to discuss ethical problems with each other in order to understand the importance of staff factors, such as different responsibilities and (overt and covert) disagreements.

\section{Who should teach?}

There now seems to be general agreement that teaching medical ethics should be an interdisciplinary activity. Experienced health care professionals and persons well trained in the humanities are required. The ideal is to have courses involving both groups of professionals as teachers in the same lecture or seminar. This, in our opinion, is important when teaching undergraduates, but especially desirable with reference to experienced staff. The faculty of the Florence course included well-known researchers and experts with different professional backgrounds: health care (epidemiology, neonatology, and obstetrics) and medical ethics (philosophy and theology). The teachers came from different European countries (Italy, the Netherlands, Spain, Sweden, and the United Kingdom), thus emphasising the relevance of cultural background.

\section{What methods should be used?}

There seems to be general agreement that a variety of methods may be used in teaching medical ethics. The choice of focus, however, is more controversial. Should teaching start with practical activities and only use principles and theories as illuminators of the problem at hand, ${ }^{8}$ or should it proceed from ethical principles or theories to practice? ${ }^{9} \mathrm{We}$ believe that the two approaches not only could, but also should, be combined. Thus, the Florence course had three main objectives. First, we provided the participants with knowledge of the main principles and theories of ethics. Second, we presented cases for identification and analysis of ethical issues. And third, we encouraged the participants to discuss the relevance of knowledge about principles and theories when trying to identify and solve the ethical problems in the cases presented. More than half of the working time was devoted to the presentation, analysis and discussion of clinical and research cases. This was preceded each morning by two introductory lectures reviewing the theoretical foundations and the basic principles of medical ethics. ${ }^{10-11} \mathrm{~A}$ guest lecture in the late afternoon opened the theme of the day to personal views and ethical issues as debated in different European countries. The main focus of the course was the case-based approach, as inspired by casuistry, ie the "method of analyzing and resolving instances of moral perplexity by interpreting general moral rules in light of particular circumstances". ${ }^{12}$ Another source of inspiration was the case method developed at the law school of Harvard University, USA, as early as $1870^{13}$ :

Figure 1: Extreme prematurity as result of induced interruption of pregnancy

\section{A CLINICAL CASE}

The story: A 23 weeks pregnant woman was referred to a tertiary medical centre. She and her partner required the interruption of pregnancy because of a perinatal infection with an estimated 5 to $10 \%$ risk of the baby developing a severe multisystem disease with brain involvement. The interruption was carried out. However, as the baby appeared alive, according to the law of the country he was intubated and admitted into the neonatal intensive care unit. The parents said they did not intend to accept this baby, and would never come to see him.

The outcome: During the following days, despite full intensive care, the baby's condition deteriorated. He developed a severe hyaline membrane disease, seizures due to a bilateral intraventricular haemorrhage, and anuria. Eventually he became comatose. A decision not to resuscitate him was made. The baby died at six days of age.

Assignment for the group work:

1. Identify the relevant ethical issues posed by this case.

2. Choose one issue for ethical analysis.

3. Identify the two most relevant options.

4. Identify the pro and con arguments.

5. Assess the arguments and make a choice. 


\section{Figure 2: The use of human fetuses/infants as research material}

\section{PROPOSAL FOR A RESEARCH PROJECT}

Rationale: Infants born too early often have respiratory distress syndrome (RDS), which today requires high-pressure mechanical ventilation using a high concentration of oxygen. But this can damage the infant's delicate lung tissues, leading to a chronic lung disease, bronchopulmonary dysplasia (BPD).

Ultimate aim of this study: To replace the high-pressure mechanical ventilator with an artificial placenta in which these infants could survive.

Research procedure: Fetuses/infants are to be obtained from pregnant women who abort voluntarily by hysterectomy, which permits abortion up to the twentieth week of gestation. The fetuses/infants are transferred to the institute's research facilities. The technique would involve cannulation of the internal iliac vessels, that is, placing a small tube in them, permitting total perfusion of the fetus/infant. No fetus/infant would be kept alive for more than two weeks due to the risk of severe damage.

Preliminary prognosis: Success would be limited during the early stages of the research: a few hours of vital signs would be realistic. It is hoped, however, that survival time will gradually increase as the technique is perfected. Adequate compensation to cover expenses would be made to the hospital supplying the fetuses/infants. Informed and voluntary consent from the women is a requirement.

Competence: There is no reason to doubt the scientific merit of the proposed research or the ability of the research teams that will undertake the study.

What is your opinion:

1. The study is ethically acceptable as it is?

2. The study is ethically acceptable, but only after revision?

3. The study is ethically unacceptable?

students were asked to work on real judicial cases rather than simply memorising legal principles and discussing hypothetical situations. This method quickly spread to most of the US law schools, and to other disciplines as well. ${ }^{14}$ In the Florence course, each day the coordinators took it in turn to introduce a case in the plenary session. Three clinical cases were presented (one is presented in figure 1). The participants where then divided into four groups, balanced in terms of gender, nationality and professional roles. Each group had to examine the same case. First, they had to identify the ethical issues at each successive stage of the evolution of the case, and choose one issue for analysis. Second, they had to identify the most relevant options (for example, continue or withdraw life support) and to list the arguments, both pros and cons. Third, they had to assess the arguments and try to come to an agreement regarding action, if necessary by voting. In dealing with the two research cases (one is presented in figure 2), a different scheme was used. Four participants, one from each group, formed a "research ethics committee" questioning the "principal investigators" (played by the course coordinators) about their research project in order to decide whether to give their approval, if necessary after changes.

At the end of the Florence course, the participants received a standard evaluation questionnaire provided by the TMR programme. A large majority considered their knowledge in the field after the event to be substantially higher than before. From the perspective of the organisers, the contributions from the participants, with their high level of competence and motivation, proved to be highly relevant. They represented a qualified group of professionals. Many of them had teaching responsibilities, significant research experience, or were running large and busy neonatal intensive care units.

\section{Concluding remarks}

The key features of this course in medical ethics for experienced staff were the interdisciplinary approach, and working in small groups with realistic cases. Confronting these cases, the participants brought into the analysis their own background and previous knowledge. The final selection of one course of action was particularly important because it required them to commit themselves and accept responsibility for their choice.

In principle, the casework can be carried out individually. It is, however, much more interesting, fruitful and fun when done through small interdisciplinary group discussion. In this way the participants may benefit from each other's knowledge, and experience the advantages and the difficulties of medical ethics as an interdisciplinary endeavour, as it is (or certainly ought to be) in actual practice.

Figure 3: Some lessons about the teaching of medical ethics to experienced staff

RECOMMENDATIONS FOR PROFESSIONAL EDUCATION

- The methods used in this course should be applied to mixed groups of clinical specialists working in the same field rather than to groups of nurses or physicians in general.

- In order to benefit from each other's knowledge and experience, the students should also work in small groups with cases.

- Success largely hinges on extensive and in-depth interaction between all participants, which becomes possible when most of them share the experience of closely similar clinical and ethical problems. 
412 Teaching and learning medical ethics: Teaching medical ethics to experienced staff: participants, teachers and method

Clinical areas other than neonatal intensive care may benefit from the case-based approach used in the course. We wish to emphasise, however, that this method should be applied to mixed groups of clinical specialists working in the same field rather than to groups of nurses or physicians in general Success in fact largely hinges-as in this course-on extensive and in-depth interaction between all participants, which becomes possible when most of them share the experience of closely similar clinical and ethical problems (figure 3 ).

\section{Acknowledgements}

The course was supported by the Programme for Training and Mobility of Researchers in Europe (TMR) of the EU (contract no ERBFMMACT960181) under the scientific responsibility of E P Whitehead. Administrative support was provided by the Istituto di Ricerca sulle Tecniche Educative e Formative (IRTEF) (Institute of Research on Educational and Teaching Techniques), Udine, Italy and technical assistance was provided by $\mathrm{S}$ Bini. Many thanks to the editor and three anonymous referees for their constructive comments. We gratefully acknowledge the contribution of guest lecturers F Abel (ES), I de Beaufort (NL), $R$ Gillon (UK), S Spinsanti (I) and U de Vonderweid (I) and of all our highly motivated students.

Tore Nilstun, PhD is Associate Professor in the Department of Medical Ethics, Lund University, Sweden. Marina Cuttini, $M D, M P H, P h D$, is a Neonatologist and Epidemiologist in the Unit of Neonatal Intensive Care and Unit of Epidemiology, Burlo Garofolo
Children's Hospital, Trieste, Italy. Rodolfo Saracci, MD, is Professor of Epidemiology in the Division of Epidemiology, IFC, National Research Council, Pisa, Italy.

\section{References}

1 Miyasaka M, Akabayashi A, Kai I, Ohi G. An international survey of medical ethics curricula in Asia. Fournal of Medical Ethics
1999;25:514-21.

2 Cuttini M, Kaminski M, Saracci R, de Vonderweid U. The EURONIC Project: a European concerted action on information to parents and ethical decision-making in neonatal mation to parents and ethical decision-making in neonatal intensive

3 Nicholas B, Gillet G. Doctors' stories, patients' stories: a narrative approach to teaching medical ethics. Fournal of Medical Ethics 1997;23:295-9.

4 Sofaer B. Enhancing humanistic skills: an experimental approach to learning about ethical issues in health care. Fournal of Medical Ethics 1995;21:31-4.

5 Sulmasy DP, Geller G, Levine DM, Faden RR. A randomized trial of ethics education for medical house officers. Fournal of Medical Ethics 1993;19:157-63.

6 Post SG, Forrow L, Arnold R, Aroskar MA, Davis AJ, Purtilo $\mathrm{RB}$, et al. Bioethics education. In: Reich WT, ed. Encyclopedia of bioethics. London/New York: Simon \& Schuster MacMillan, 1995: 256-72.

7 Fulford KW, Yates A, Hope T. Ethics and the GMC core curriculum: a survey of resources in UK medical schools. Fournal of Medical Ethics 1997;23:82-7.

8 Tysinger JW, Klonis LK, Sadler JZ, Wagner JM. Teaching ethics using small-group, problem-based learning. Fournal of ics using small-group, prob

9 Singer P, ed. Applied ethics. Oxford: Oxford University Press, 1986.

10 Beauchamp TL, Childress JF. Principles of biomedical ethics [4th ed]. Oxford: Oxford University Press, 1994.

11 Gillon R. Medical ethics: four principles plus attention to scope. British Medical fournal 1994;309:184-8.

12 Jonsen AR. Casuistry. In: Reich WT, ed. Encyclopedia of bioethics. London/New York: Simon \& Schuster MacMillan, 1995: 344-50.

13 Neely A. Cases: what they are and how to study them. Boston: ICCH, 1979.

14 Andrews $\mathrm{K}$, ed. The case method of teaching human relations and administration. Cambridge: Harvard University Press, 1960. 